(C) 1980. The Genetical Society of Great Britain

\title{
ADAPTATION OF DROSOPHILA WILLISTONI EXPERIMENTAL POPULATIONS TO EXTREME $P H$ MEDIUM
}

\section{DEVELOPMENT OF INCIPIENT REPRODUCTIVE ISOLATION}

\author{
ALICE KALISZ de OLIVEIRA* and ANTONIO RODRIGUES CORDEIRO† \\ * Departamento de Genética, Cx. Postal 1953, Univ. Federal do Rio Grande do Sul, 90.000, Porto \\ Alegre, R.G.S.,Brasil; †Departamento de Genética, Cx.Postal 68.011, U.F.R.J., Cidade Universitória, \\ 21.941, Rio de Janeiro, R.J., Brasil
}

Received 11.vii.79

\section{SUMMARY}

\begin{abstract}
Experimental populations of Drosophila willistoni adapted to low, median and high $p \mathrm{H}$ substrate $(p \mathrm{H} 2, p \mathrm{H} 5$ and $p \mathrm{H} \mathrm{10)}$ were tested by the multiple choice technique, and a significant sexual preference was observed for homogamic insemination, which was greater among populations derived from the centre of the species distribution than the ones collected near the margin of its distribution range. It was also observed that some of the $F_{1}$ and $F_{2}$ hybrids, between flies adapted to different foods, were reproductively inferior on the parental substrate.

The greater divergence of the central populations may be due to their significantly greater chromosomal and genic polymorphism than the margina populations.
\end{abstract}

\section{INTRODUCTION}

INDIRECT and direct selective processes may contribute to the initiation of reproductive isolation between spatially isolated populations (Littlejohn, 1969). Incipient isolation usually starts with minor changes in courtship and hybrid male sterility, as Winge (1971) demonstrated in Drosophila willistoni quechua (Ayala, 1973). The complexity of natural environments and the lack of detailed ecological information on the factors responsible for race and species divergence in Drosophila make it desirable to use an experimental approach to establish the agents and the time necessary to start and develop incipient reproductive isolation in allopatric or sympatric conditions. Knight, Robertson and Waddington (1956), Thoday and Gibson (1962, 1970), Gibson and Thoday (1963), Ehrman (1964), Del Solar (1966), Scharloo (1967), Chabora (1968), and others have contributed significantly to this field.

In this experiment we report the detection of incipient isolation between separated experimental populations of $D$. willistoni adapted for many generations to three types of food having different $p \mathrm{H}$ levels.

\section{Material and methods}

A detailed description of the experimental populations is given by Oliveira and Cordeiro (1980) and a brief outline of methods will suffice. Samples of the $D$. willistoni natural populations were collected in riparian 
woods at the National Park near Brasilia, D.F., and in semi-isolated woods of the grassland region of Rio Grande do Sul state in the "Eldorado" locality, Guaíba County. The $\mathrm{F}_{1}$ generation from each sample was distributed between three population cages for Brasilia and three for Eldorado. The cages had 12 food containers each. In the next generation each cage contributed to three others with the same kind of food, giving a total of nine Brasilia and nine Eldorado cages. In successive generations the number of containers with extreme $p \mathrm{H}$ food was gradually increased in the respective population cages so that ultimately there were, for each locality, three cages with only low $p \mathrm{H}$ food ( $p \mathrm{H} 2-3$ ), three with only high $p \mathrm{H}$ food (9-10) while three remained unchanged with the standard food $(p \mathrm{H} 5)$, here named median $p \mathrm{H}$. The symbols to represent the cages are: $\mathrm{B}=$ Brasilia and $\mathrm{E}=$ Eldorado, followed by: $1=$ low, $\mathrm{m}=$ median, and $\mathrm{h}=$ high, for the three levels of $p \mathrm{H}$. The populations were numbered in order: $\mathrm{Bl}_{1}, \mathrm{Bl}_{2}, \mathrm{Bl} / \mathrm{Bm}_{1}$, $\mathrm{Bm}_{2}, \mathrm{Bm}_{3}, \mathrm{Bh}_{1}, \mathrm{Bh}_{2}, \mathrm{Bh}_{3}, \mathrm{El}_{1}$, etc.

Sexual isolation was studied by the multiple choice technique. The flies were sexed and aged for 3 days. The vials used for maturation of these flies were examined afterwards to control mistakes. We found after several trials that it is adequate for this test to place together 3-day-old males and females for only 4 hours at $25^{\circ} \mathrm{C}$. The testing was terminated by immobilising the flies in an $8^{\circ} \mathrm{C}$ thermostable chamber until the females could be dissected and their ventral receptacle and spermathecae examined under a microscope for mobile spermatozoa. For the calculation of Levene's (1949) coefficient of isolation $\left(\mathrm{K}_{1,2}\right)$, population 1 males are placed with population 1 and population 2 females and the number of intra and inter-population inseminations are counted. The inverse crosses are tested using No. 2 males with Nos. 2 and 1 females. The formulae used are:

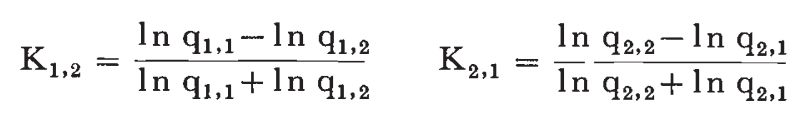

Where $1-q_{i j}$ is the frequency of insemination of females of type $j$ by males of type $i$. Standard errors of these values can be calculated according to Levene (1949).

The coefficient of joint isolation of two populations is given by the arithmetic mean: $\mathrm{K}_{1,2}=\left(\mathrm{K}_{1,2}+\mathrm{K}_{2,1}\right) / 2$ and the coefficient of excess insemination: $\mathrm{m}_{1,2}=\left(\mathrm{K}_{1,2}-\mathrm{K}_{2,1}\right) / 2$. The joint coefficient measures the true reproductive isolation between the two populations under the artificial conditions of the experiment, while the coefficient of excess insemination can serve as a measure of the extent to which the gene flow between the two populations is in one direction only.

Another measurement of reproductive isolation tested in this work is defined as "hybrid inferiority" under the parental medium conditions. For this test, 5-day-old virgin females and males were used. All possible crosses among Brasilia populations were made. For each combination two replicate crossings were started with 10 pairs of flies which were transferred every 2 nd day to a new culture bottle, giving two series of six bottles with the appropriate $p \mathrm{H}$ substrate. The eclosed progeny flies were counted and again two sets of 10 pairs were mated and transferred as above to make two replicate series of six vials for each combination. The emerging flies were counted as a measure of their productivity. 


\section{Results}

The multiple choice sexual isolation tests were performed after 26, 32, 52 , and 69 generations of selection for the three different $p \mathrm{H}$ foods in the Brasilia populations as summarised in table 1. It can be observed that according to the Levene (1949) index there is a significantly greater frequency of homogamic insemination in the following crosses: males high $\times$ low + high females; males median $\times$ median + low females; and males low $\times$ median + low females. However in the 52nd generation the crossing of males high $\times$ low + high females, and males median $\times$ median + low females shows no significant results. It is possible that the relatively smaller sample tested, and a sporozoan infection observed in this generation could have interfered with the

\section{TABLE 1}

Sexual isolation between D. willistoni populations from Brasilia selected for different $\mathrm{p} H$ levels $(M=$ Intermediate; $H=$ high and $L=$ low $\mathrm{pH}$ medium; $n=$ number of examined fies; \% inseminated flies)

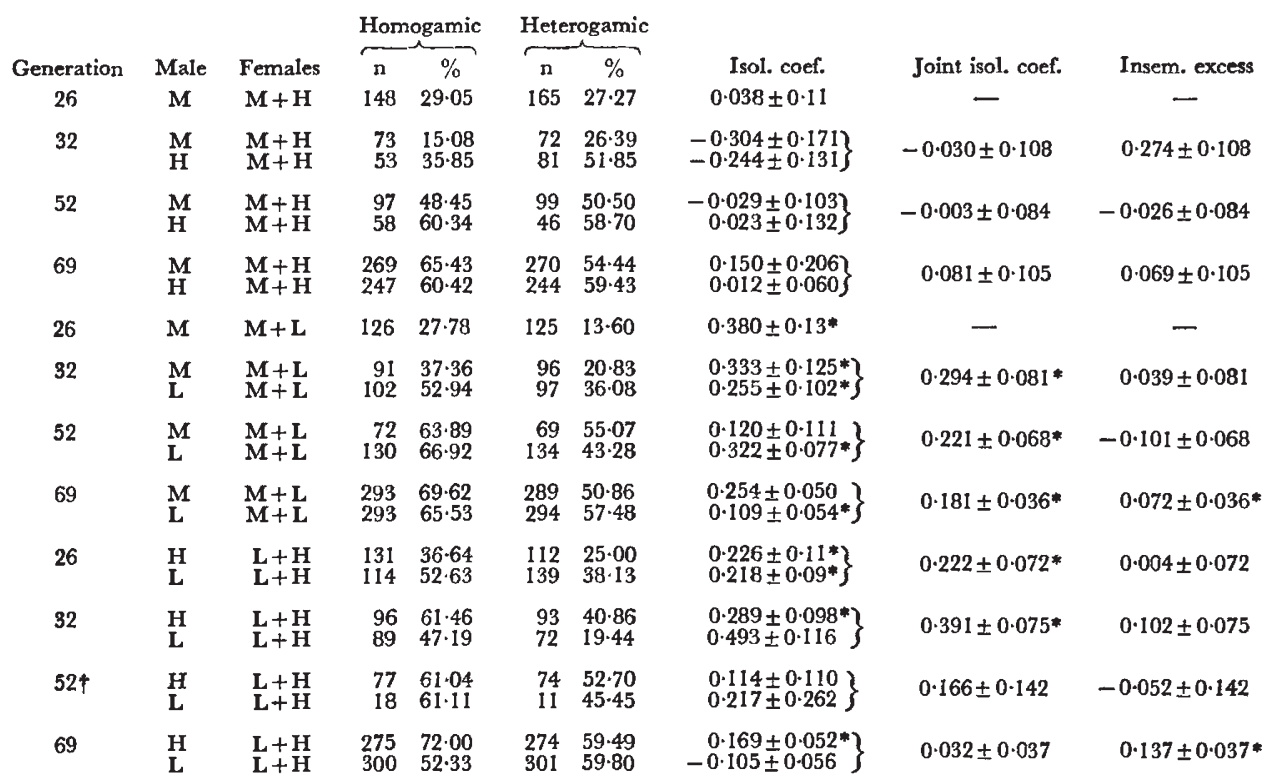

* Homogamic insemination significantly greater than the heterogamic. + Sporozoan infection.

outcome of this experiment. Nevertheless, the crosses: males low $\times$ median + low females shows significant homogamic sexual preference.

The same kind of multiple choice tests was performed for the Eldorado experimental populations after 34,52, and 69 generations of selection. The results are summarised in table 2 . The most consistent incipient isolation by sexual preference was exhibited by the males median $\times$ median + low females where the homogamic inseminations were more frequent than the heterogamic. In the Eldorado crossings of males low $\times$ low + high females, males median $\times$ median + high females, and males low $\times$ median + low females, significant homogamic preferences were observed only in one of the generations. There was not a continuity of response as in Brasilia's populations. 
TABle 2

Sexual isolation between $\mathrm{D}$. willistoni populations from Eldorado selected for different $\mathrm{pH}$ levels $(M=$ intermediate; $H=$ high and $L=$ low $\mathrm{pH}$ medium; $n=$ number of examined flies; $\%$ inseminated fies

\begin{tabular}{|c|c|c|c|c|c|c|c|c|c|}
\hline \multirow[b]{2}{*}{$\begin{array}{c}\text { Generation } \\
34\end{array}$} & \multirow[b]{2}{*}{$\begin{array}{c}\text { Male } \\
\mathbf{M} \\
\mathbf{H}\end{array}$} & \multirow[b]{2}{*}{$\begin{array}{c}\text { Females } \\
M+H \\
M+H\end{array}$} & \multicolumn{2}{|c|}{ Homogamic } & \multicolumn{2}{|c|}{ Heterogamic } & \multirow[b]{2}{*}{$\left.\begin{array}{c}\text { Isol. coef. } \\
0 \cdot 006 \pm 0.098 \\
0 \cdot 156 \pm 0.093\end{array}\right\}$} & \multirow[b]{2}{*}{$\begin{array}{l}\text { Joint isol. coef. } \\
0.082 \pm 0.067\end{array}$} & \multirow[b]{2}{*}{$\begin{array}{r}\text { Insem. excess } \\
-0.075 \pm 0.067\end{array}$} \\
\hline & & & $\begin{array}{c}n \\
103 \\
106\end{array}$ & $\begin{array}{c}\% \\
53 \cdot 40 \\
58 \cdot 49\end{array}$ & $\begin{array}{c}\mathrm{n} \\
102 \\
112\end{array}$ & $\begin{array}{c}\% \\
52.94 \\
47 \cdot 32\end{array}$ & & & \\
\hline 52 & $\stackrel{\mathrm{M}}{\mathrm{H}}$ & $\begin{array}{l}\mathrm{M}+\mathrm{H} \\
\mathbf{M}+\mathrm{H}\end{array}$ & $\begin{array}{l}39 \\
49\end{array}$ & $\begin{array}{l}79 \cdot 49 \\
71 \cdot 43\end{array}$ & $\begin{array}{l}38 \\
44\end{array}$ & $\begin{array}{l}68 \cdot 42 \\
70 \cdot 45\end{array}$ & $\left.\begin{array}{l}0.158 \pm 0.140 \\
0.013 \pm 0.131\end{array}\right\}$ & $0.085 \pm 0.096$ & $0.073 \pm 0.096$ \\
\hline 69 & $\stackrel{\mathrm{M}}{\mathrm{H}}$ & $\begin{array}{l}\mathrm{M}+\mathrm{H} \\
\mathrm{M}+\mathrm{H}\end{array}$ & $\begin{array}{l}278 \\
299\end{array}$ & $\begin{array}{l}67.27 \\
66.55\end{array}$ & $\begin{array}{l}280 \\
292\end{array}$ & $\begin{array}{l}48 \cdot 21 \\
69 \cdot 52\end{array}$ & $\left.\begin{array}{r}0.263 \pm 0.071 * \\
-0.041 \pm 0.053\end{array}\right\}$ & $0.111 \pm 0.044^{*}$ & $0.152 \pm 0.044^{*}$ \\
\hline 34 & $\begin{array}{l}\mathrm{M} \\
\mathrm{L}\end{array}$ & $\begin{array}{l}\mathrm{M}+\mathrm{L} \\
\mathbf{M}+\mathbf{L}\end{array}$ & $\begin{array}{l}117 \\
129\end{array}$ & $\begin{array}{l}52.99 \\
41.86\end{array}$ & $\begin{array}{l}125 \\
124\end{array}$ & $\begin{array}{l}33 \cdot 60 \\
31 \cdot 45\end{array}$ & $\left.\begin{array}{l}0.297 \pm 0.091 * \\
0.179 \pm 0.102\end{array}\right\}$ & $0.238 \pm 0.068 *$ & $0.059 \pm 0.068$ \\
\hline 52 & $\begin{array}{l}\mathrm{M} \\
\mathbf{L}\end{array}$ & $\begin{array}{l}\mathbf{M}+\mathbf{L} \\
\mathbf{M}+\mathbf{L}\end{array}$ & $\begin{array}{l}69 \\
74\end{array}$ & $\begin{array}{l}84 \cdot 05 \\
86 \cdot 49\end{array}$ & $\begin{array}{l}69 \\
78\end{array}$ & $\begin{array}{l}59 \cdot 42 \\
48 \cdot 72\end{array}$ & $\left.\begin{array}{l}0.342 \pm 0.097 * \\
0.500 \pm 0.082 *\end{array}\right\}$ & $0.079 \pm 0.063$ & $0.421 \pm 0.063^{*}$ \\
\hline 69 & $\stackrel{\mathrm{M}}{\mathrm{L}}$ & $\begin{array}{l}M+L \\
M+L\end{array}$ & $\begin{array}{l}290 \\
294\end{array}$ & $\begin{array}{l}63 \cdot 10 \\
63 \cdot 94\end{array}$ & $\begin{array}{l}290 \\
294\end{array}$ & $\begin{array}{l}49 \cdot 65 \\
64 \cdot 63\end{array}$ & $\left.\begin{array}{r}0.185 \pm 0.053 * \\
-0.009 \pm 0.053\end{array}\right\}$ & $0.098 \pm 0.037 *$ & $0.097 \pm 0.037 *$ \\
\hline 34 & $\underset{\mathrm{L}}{\mathrm{H}}$ & $\begin{array}{l}\mathrm{L}+\mathrm{H} \\
\mathrm{L}+\mathrm{H}\end{array}$ & $\begin{array}{l}97 \\
83\end{array}$ & $\begin{array}{l}50.51 \\
57.83\end{array}$ & $\begin{array}{l}96 \\
89\end{array}$ & $\begin{array}{l}39.58 \\
33.71\end{array}$ & $\left.\begin{array}{l}0 \cdot 165 \pm 0.106 \\
0.355 \pm 0.104\end{array}\right\}$ & $0.260 \pm 0.074^{*}$ & $-0.095 \pm 0.074$ \\
\hline 52 & $\begin{array}{l}\mathrm{H} \\
\mathrm{L}\end{array}$ & $\begin{array}{l}\mathrm{L}+\mathrm{H} \\
\mathrm{L}+\mathrm{H}\end{array}$ & $\begin{array}{l}44 \\
50\end{array}$ & $\begin{array}{l}75.00 \\
86.00\end{array}$ & $\begin{array}{l}47 \\
48\end{array}$ & $\begin{array}{l}68.08 \\
75.00\end{array}$ & $\left.\begin{array}{l}0 \cdot 096 \pm 0 \cdot 131 \\
0 \cdot 173 \pm 0 \cdot 123\end{array}\right\}$ & $0.137 \pm 0.089$ & $0.040 \pm 0.089$ \\
\hline 69 & $\underset{\mathrm{L}}{\mathrm{H}}$ & $\begin{array}{l}\mathrm{L}+\mathrm{H} \\
\mathrm{L}+\mathrm{H}\end{array}$ & $\begin{array}{l}282 \\
285\end{array}$ & $\begin{array}{l}64 \cdot 89 \\
62 \cdot 10\end{array}$ & $\begin{array}{l}285 \\
282\end{array}$ & $\begin{array}{l}62 \cdot 10 \\
66 \cdot 31\end{array}$ & $\left.\begin{array}{r}0.011 \pm 0.056 \\
-0.037 \pm 0.054\end{array}\right\}$ & $-0.024 \pm 0.039$ & $0.013 \pm 0.039$ \\
\hline
\end{tabular}

In the 106th generation of selection the Brasilia experimental populations were sampled and crossed as indicated, in order to find out whether reproductive isolation in the form of reduced hybrid viability in the parental environments could be detected. The results are presented in table 3 . Despite the fact that high and low populations have developed quite significant differences with regard to their food medium their hybrids are not less fit on the alkaline food. However, on the acid substrate the hybrids are inferior to their parents which are adapted to this food; the productivity of the hybrids at the low $p \mathrm{H}$ is nevertheless better than that of the high $p \mathrm{H}$ parents. The hybrids are even more viable in the high $p \mathrm{H}$ than their low

TABLE 3

Reproductive isolation due to hybrid inferiority between D. willistoni populations from Brasilia selected for 106 generations for adaptation to extreme $\mathrm{pH}$ values of the medium

\begin{tabular}{|c|c|c|c|c|c|}
\hline \multicolumn{3}{|c|}{$F_{1}$} & \multicolumn{3}{|c|}{$\mathrm{F}_{2}$} \\
\hline$\sigma \times q$ & $\bar{X}$ & $\operatorname{High}^{t} p \mathrm{H}$ & 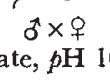 & $\bar{X}$ & $t$ \\
\hline $\mathrm{H} \times \mathrm{H}$ & $26 \cdot 82$ & - & $\mathrm{H} \times \mathrm{H}$ & $53 \cdot 21$ & - \\
\hline $\mathrm{L} \times \mathrm{L}$ & 12.86 & $3 \cdot 20 \dagger$ & $\mathrm{L} \times \mathrm{L}$ & $46 \cdot 42$ & $2 \cdot 26^{*}$ \\
\hline $\mathrm{H} \times \mathrm{L}$ & $29 \cdot 00$ & 0.47 & $\mathrm{H} \times \mathrm{L}$ & 68.92 & $3.01 *$ \\
\hline
\end{tabular}

Low $p \mathrm{H}$ substrate, $p \mathrm{H} 2$

$\begin{array}{lrrrrr}\mathrm{L} \times \mathrm{L} & 30 \cdot 25 & - & \mathrm{L} \times \mathrm{L} & 30 \cdot 28 & - \\ \mathrm{H} \times \mathrm{H} & 3.96 & 9 \cdot 70 \dagger & \mathrm{H} \times \mathrm{H} & 5 \cdot 88 & 4 \cdot 49 \dagger \\ \mathrm{H} \times \mathrm{L} & 13.32 & 6 \cdot 16 \dagger & \mathrm{L} \times \mathrm{H} & 14.35 & 2 \cdot 63 *\end{array}$

Significant at a level of $0 \cdot 05$. + Significant at a level of $0 \cdot 01$. $\bar{X}$ Eclosed flies from a pair mating (2 days oviposition). 
TABLE 4

Reproductive isolation due to hybrid inferiority between D. willistoni population from Brasilia selected during 122 generations to extreme $\mathrm{pH}$ medium

\begin{tabular}{|c|c|c|c|c|c|}
\hline \multicolumn{3}{|c|}{$F_{1}$} & \multicolumn{3}{|c|}{$\mathbf{F}_{2}$} \\
\hline \multicolumn{5}{|c|}{ Low $p \mathrm{H}$ substrate } & $t$ \\
\hline $\mathrm{L} \times \mathrm{L}$ & $16 \cdot 82$ & - & $\mathrm{L} \times \mathrm{L}$ & $3 \cdot 71$ & - \\
\hline $\mathbf{M} \times \mathbf{M}$ & $4 \cdot 96$ & $5 \cdot 38 *$ & $\mathbf{M} \times \mathbf{M}$ & $2 \cdot 68$ & $1 \cdot 30$ \\
\hline $\mathbf{H} \times \mathbf{H}$ & $3 \cdot 28$ & $6 \cdot 28 *$ & $\mathrm{H} \times \mathrm{H}$ & $1 \cdot 64$ & $2.87 *$ \\
\hline $\mathrm{L} \times \mathrm{M}$ & $6 \cdot 78$ & $4 \cdot 13 \dagger$ & $\mathrm{L} \times \mathrm{M}$ & $1 \cdot 50$ & $3 \cdot 16 \dagger$ \\
\hline $\mathrm{M} \times \mathrm{L}$ & 13.96 & 0.99 & $\mathrm{M} \times \mathrm{L}$ & $3 \cdot 18$ & 0.59 \\
\hline $\mathrm{L} \times \mathrm{H}$ & $6 \cdot 07$ & $4 \cdot 52 \uparrow$ & $\mathrm{L} \times \mathrm{H}$ & 1.75 & $2 \cdot 48 *$ \\
\hline $\mathrm{H} \times \mathrm{L}$ & $11 \cdot 71$ & $1 \cdot 88^{\circ}$ & $\mathrm{H} \times \mathrm{L}$ & $4 \cdot 07$ & $0 \cdot 40$ \\
\hline
\end{tabular}

Intermediate $p \mathrm{H}$ substrate

\begin{tabular}{|c|c|c|c|c|c|}
\hline $\mathrm{M} \times \mathbf{M}$ & $37 \cdot 11$ & - & $\mathbf{M} \times \mathbf{M}$ & 37.89 & - \\
\hline $\mathbf{L} \times \mathbf{L}$ & 18.57 & $4.96 \dagger$ & $\mathrm{L} \times \mathrm{L}$ & $16 \cdot 68$ & $7 \cdot 34 \dagger$ \\
\hline $\mathrm{H} \times \overline{\mathrm{H}}$ & 8.86 & $8.85 \dagger$ & $\mathbf{H} \times \mathbf{H}$ & $30 \cdot 82$ & $2 \cdot 15^{*}$ \\
\hline $\mathrm{M} \times \mathrm{L}$ & $29 \cdot 68$ & $2 \cdot 39 *$ & $\mathrm{M} \times \mathrm{L}$ & $44 \cdot 21$ & 1.99 \\
\hline $\mathrm{L} \times \mathrm{M}$ & $35 \cdot 89$ & 0.37 & $\mathrm{~L} \times \mathrm{M}$ & $33 \cdot 25$ & $1 \cdot 34$ \\
\hline $\mathrm{M} \times \mathrm{H}$ & $28 \cdot 86$ & $2 \cdot 48$ * & $\mathbf{M} \times \mathbf{H}$ & $41 \cdot 32$ & $1 \cdot 21$ \\
\hline $\mathrm{H} \times \mathrm{M}$ & $25 \cdot 50$ & $3 \cdot 34 \dagger$ & $\mathrm{H} \times \mathbf{M}$ & $35 \cdot 07$ & 0.89 \\
\hline
\end{tabular}

$\begin{array}{cccccc}\mathbf{H} \times \mathbf{H} & 30.11 & - & \mathbf{H} \times \mathbf{H} & 35.61 & - \\ \mathbf{M} \times \mathbf{M} & 26.96 & 1.07 & \mathbf{M} \times \mathbf{M} & 26.25 & 4.68 \dagger \\ \mathbf{L} \times \mathbf{L} & 22.71 & 2.40^{*} & \mathbf{L} \times \mathbf{L} & 19.54 & 7.51 \dagger \\ \mathbf{H} \times \mathbf{L} & 27.71 & 0.62 & \mathbf{H} \times \mathbf{L} & 33.36 & 0.86 \\ \mathbf{L} \times \mathbf{H} & 29.75 & 0.10 & \mathbf{L} \times \mathbf{H} & 34.57 & 0.46 \\ \mathbf{H} \times \mathbf{M} & 26.93 & 0.90 & \mathbf{H} \times \mathbf{M} & 27.96 & 3.73 \dagger \\ \mathbf{M} \times \mathbf{H} & 22.28 & 2.63^{*} & \mathbf{M} \times \mathbf{H} & 34.32 & 0.70\end{array}$

* Significant at a level of $0 \cdot 05$. $†$ Significant at a level of 0.01 . $\bar{X}$ Eclosed flies from a pair mating (2 days oviposition). ( $\mathrm{M}=$ intermediate; $\mathrm{L}=$ low $; \mathrm{H}=\operatorname{high} \rho \mathrm{H}$ medium. $)$

$p \mathrm{H}$ parents. In the 122nd generation of selection the same tests were carried out and table 4 shows the data obtained for the $F_{1}$ and $F_{2}$. When the average production per pair mating is compared, most of these results confirm the results for the 106th generation. Again, on the alkaline food the low/high hybrids are not significantly inferior to their high parents. The opposite was observed for the low $p \mathrm{H}$ parents which were significantly better on their food than any hybrid except for the median/low and high/low combinations. However, pooling of median/low + low/median and high/low + low/high, the $\mathrm{F}_{1}$ and $\mathrm{F}_{2}$ hybrids are significantly inferior to their low parents on the acid food. At the median $p \mathrm{H}$ food ( $p \mathrm{H} 5)$ the hybrids high/median and median/high are significantly less productive than the flies adapted to this intermediate $p \mathrm{H}$ level which are not better than the hybrids low/median but are better than the median/low in this food. If the viabilities of these reciprocal hybrids are pooled the result is significantly inferior to the median population in the $\mathrm{F}_{1}$. In the $\mathrm{F}_{2}$ generation hybrid inferiority appears only in three out of twelve combinations while in $\mathrm{F}_{1}$ the proportion is six to twelve. If we pool the reciprocal hybrid crossings this difference increases. 


\section{Discussion}

Experimental populations from Brasilia show very significant, consistent incipient sexual isolation in three different multiple choice tests (males median $\times$ median + low females, low $\times$ low + median females, and males high $\times$ low + high females). The only consistently significant result shown by the Eldorado populations was produced by the crossings of males median $\times$ median + low females. These results might be related to the fact that the Central Brazilian region (Brasilia) populations have higher frequencies of genic and chromosomal polymorphism than the southern marginal populations of Rio Grande do Sul (Eldorado) according to Pavan et al. (1951), Cordeiro et al. (1958), Da Cunha and Dobzhansky (1954). The other three cases of significant results are scattered throughout different combinations (table 2). In D. melanogaster strains isolated for many generations, KorefSantibañez and Waddington (1958) showed occasional preferences for homogamic matings in male choice experiments in four of six strains, two of them showing also female homogamic preference. These results, like those observed in the Eldorado populations, suggest that incipient sexual isolation may appear as a chance event among spatially isolated populations. However the more consistent results of Brasilia populations are best compared with those of the Mather and Harrison (1949) strains selected for abdominal chaeta number. Sexual isolation may be a frequent result concomitant with genetic divergence.

Low $p \mathrm{H}$ populations definitely produced more significant results. No isolation was detected between median and high $p \mathrm{H}$ populations in Brasilia or Eldorado, except for one case in the latter populations. The comparison of the reproductive performance of $\mathrm{F}_{1}$ hybrids and their parents in the respective culture media suggests that low $p H$ food was more effective as a selective agent than high $p H$ food.

The first known test of sexual isolation in $D$. willistoni populations was performed by Dobzhansky and Mayr (1944) for flies from Quirigua, Guatemala and four other locations in Brasil. Incipient sexual homogamic preference was shown only by Brazilian flies, while Guatemalian males preferred Brazilian females. Recently Dobzhansky (1975) showed that $D$. willistoni quechua shows a barely significant sexual isolation index, calculated by the method also used by us. Despite minor differences in the technique of multiple choice testing, our results are comparable with those of Dobzhansky (1975). It is surprising that selection for extreme environments could be so fast and so effective in producing ethologic isolation between flies of the same species and location, at a level observed among naturally occurring subspecies. In Zea mays L., Patterniani (1969) developed intraspecific sexual isolation through selection in only six generations.

Unfortunately we did not test hybrid male sterility, which was found to be the most important isolation factor among $D$. willistoni geographic races (De Souza et al., 1961, De Toledo, 1971, and Winge, 1971). The distinction of $D$. willistoni into three geographic races was proposed by Winge, after extensive studies, as: the northern (Central America, West Indies, except Trinidad, and southern Florida), southern (Brasil, Argentina, Colombia and Trinidad), and the transitional race (Peru and Equador) which corresponds to the subspecies named $D$. willistoni quechua by Ayala (1973). These flies are morphologically indistinguishable, yet the high degree of probability 
of correct diagnosis of the subspecies on a single individual, with the aid of isoenzyme patterns, ranges from 0.99998 to 0.974 for each of the five loci Ayala and Tracey (1973) used to describe the subspecies. The five loci give the joint probability of $3.4 \times 10^{-14}$ for the incorrect diagnosis of the subspecies of a single individual. According to Reguly and Cordeiro (1978) our high and low populations differ in the allelic frequency of two out of four loci studied, and we have indications that other enzymatic systems show allozymic variations between populations. Allozymes appear to be good markers of genetic divergence among Drosophila species as demonstrated by Ayala and Powell (1972) for the willistoni sibling group of species.

Acknowledgments.-We are grateful to F. W. Robertson, F. J. Ayala and W. E. Kerr for their critical readings of this paper, and to Miss Nena B. Morales for the excellent technical assistance. This research was supported in part by the Fundaçáo de Amparo a Pesquisa do Estado do Rio Grande do Sul and the Conselho Nacional de Desenvolvimento Cientifico e Tecnologico.

\section{ReFERENGES}

Ayala, F. J. 1973. Two new subspecies of the Drosophila willistoni groups (Diptera : Drosophilidae). Pan Pacific Entomologist, 49, 273-279.

AYALA, F. J., AND POWELL, J. B. 1972. Allozymes as diagnostic characters of sibling species of Drosophila. Proc. Natl. Acad. Sci., 69, 1094-1096.

AYALA, F. J., AND TRACEY, M. L. 1973. Enzyme variability in the D. willistoni group. VIII. Genetic differentiaiion and reproductive isolation between two subspecies. $\mathcal{F}$. Hered., $64,120-124$.

GHABORA, A. J. 1968. Disruptive selection for sternopleural chaeta number in various strains of $D$. melanogaster. Amer. Natur., 102, 525-532.

CORdeiro, A. R., TOWSEND, J. I., PETERSEN, J. A., AND JAEGER, E. C. 1958. Genetics of southern marginal populations of Drosophila willistoni. Proc. X Inter. Congr. Genet. Montreal, 3, 58-59.

DA CUNHA, A. B., AND DOBZHANSKY, TH. 1954. A further study of chromosomal polymorphism in $D$. willistoni in its relation to the environment. Evolution, 8, 119-134.

DE sOUZA, H. L., DE TOLEDO, J. s., AND PAVAN, C. 1961. Incompatibilidade cromossomica e esterilidade masculina em D. willistoni. Atas do I Simpósio Sul-Americano de Genética, 303-305 (São Paulo).

DE TOLEDo, c. J. 1971. Estudo da esterilidade entre diferentes linhagens de $D$. willistoni. Rev. Brasil. Biol., 31, 145-151.

DEL SOLAR, E. 1966. Sexual isolation caused by selection for positive and negative phototaxis and geotaxis in Drosophila pseudoobscura. Proc. Nat. Acad. Sci. (US), 56, 484-487.

DOBZHANSKY, TH. 1975. Analysis of incipient reproductive isolation within a species of Drosophila. Proc. Nat. Acad. Sci., (US), 72 (9), 3638-3641.

DOBZHANSKy, TH., AND MAYR, E. 1944. Experiment on sexual isolation in Drosophila. I. Geographic strains of $D$. willistoni. Proc. Nat. Acad. Sci., 30, 238-244.

EHRMAN, L. 1964. Genetic divergence in M. Vetukhiv's experimental populations of D. pseudoobscura. Genet. Res., 5, 150-157.

GIBson, J. s., AND THODAy, J. M. 1963. Effects of disruptive selection. VIII. Imposed quasi-random mating. Heredity, 18, 513-524.

KNIGHT, G. R., ROBERTSON, A., AND WADDINGTON, C. H. 1956. Selection for sexual isolation within a species. Evolution, 10, 14-22.

KOREF-SANTIBAÑEZ, S., AND WADDINGTON, c. H. 1958. The origin of isolation between different lines within a species. Evolution, 12, 485-493.

LEVENE, H. 1949. A new measure of sexual isolation. Evolution, 3, 315-321.

LITTLEJOHN, M. J. 1969. The systematic significance of isolating mechanisms. In Systematic Biology, pp. 459-482. Nat. Acad. Sci. (US), Publ. no. 1692, Washington.

MATHER, K., AND harrison, B. J. 1949. The manifold effect of selection. Heredity, 3, 1-52, 131-162. 
Oliveira, A. K., AND CORdeiro, A. R. 1980. Adaptation of Drosophila willistoni experimental populations to extreme $p \mathrm{H}$ medium. I. Changes in viability and developmental rate. Heredity, 44, 111-122.

PATtERniani, E. 1969. Selection for reproductive isolation between two populations of maize, Zea mays L. Evolution, 23, 534-547.

PAVAN, C., CORDEIRO, A. R., DOBZHANSKY, N., DOBZHANSKY, TH., MALOGOlOVKIN, C., SPASSKY, s., AND WEDEL, N. 195l. Concealed genic variability in Brazilian population of $D$. willistoni. Genetics, 36, 13-30.

REGULY, M. L., AND CORDEIRO, A. R. 1980. Adaptation of $D$. willistoni experimental populations to extreme $p \mathrm{H}$ medium. III. Esterase polymorphism (in prep.).

sharloo, w. 1967. Disruptive selection on sternopleural chaeta number. Genet. Res., 9, 115-118.

THODAY, J. M., AND GIBSON, J. B. 1962. Isolation by disruptive selection. Nature, 193, 1164-1166.

THODAY, J. M., AND GiBson, J. B. 1970. The probability of isolation by disruptive selection. Amer. Natur., 104, 219-230.

WINGE, H. 1971. Níveis de divergência evolutiva no grupo criptico da D. willistoni. Tese de doutoramente apresentada ao curso de pós-graduação da UFRGS. 